\title{
KONSTRUKSI PRESENTASI DIRI: STUDI PADA PRIA METROSEKSUAL DI INSTANSI PEMERINTAHAN
}

\author{
Dianita Wahyuningtyas \\ Program Studi Ilmu Komunikasi Fakultas Ilmu Sosial dan Ilmu Politik \\ Universitas Sebelas Maret \\ Email: ditadianita210@gmail.com
}

\begin{abstract}
Urban modernization has affected the behavior of the people in it. Today, real phenomenon is the emergence of an urban men's lifestyle who really cares about her physical appearance like women. Previously, this lifestyle initially seen as hegemony and monopoly media celebrities, now replicated by people in everyday appearance, including a group of men in certain professions.

The phenomenon of the metrosexual man in the government bureaucracy becomes interesting to study which stereotypes that the government bureaucracy are closed and rigid culture. Construction self-presentation shows an overview of social identity and self esteem. This study used a qualitative descriptive exploratory approach through the case study method. With purposive sampling technique, researchers determined the study subjects according to general characteristics of the metrosexual men. Researchers conducted in-depth interviews on four informants metrosexual men in the Ministry of Finance with a different of profession, age, and status.

The conclusion is informant's lifestyle more positively oriented. They tend narcissism, tidy, fashionoriented and more consumptive. Through informan's self-presentation, the results show that bodyguard professions more recently adopting the metrosexual lifestyle than any other professions. Based on the characteristics of the AIO, the results showed four types of metrosexual men lifestyle, among other types of sport, trendy, automotive and artistic.

Motivation of informan's behavior in line with the general metrosexual cycle. Diverse motives behind the desire informant lifestyle look attractive especially to the opposite sex, work demands, and also increase comfort in social interaction. However, the phases of the metrosexual were experienced by the informants 'non-linear' as in general. While associated with the consumption patterns, the entire informants have high interest to the consumer. The findings showed that all informants included in the category of impulsive buyers who think rationally and selectively.
\end{abstract}

Keywords: Lifestyle; Metrosexual; Modernization; Self presentation.

\begin{abstract}
ABSTRAK
Modernisasi perkotaan telah mempengaruhi perilaku masyarakat di dalamnya. Fenomena nyata adalah munculnya pergeseran gaya hidup pria perkotaan yang sangat peduli pada penampilan fisiknya layaknya kaum wanita. Gaya hidup yang semula dipandang sebagai hegemoni media dan monopoli kalangan selebriti, bergeser dan ditiru oleh masyarakat dalam penampilan sehari-hari, termasuk kelompok pria pada profesi tertentu.

Fenomena pria metroseksual di kalangan birokrasi pemerintah menjadi hal mernarik untuk diteliti ditengah stereotipe masyarakat atas birokrasi pemerintah dengan budaya tertutup dan kaku. Konstruksi presentasi diri pria metroseksual menunjukkan gambaran identitas sosial dan self esteem pada dirinya. Penelitian ini menggunakan pendekatan deskriptif kualitatif eksploratif melalui metode studi kasus. Melalui teknik purposive sampling, peneliti menentukan subyek penelitian menurut karakteristik
\end{abstract}


umum pria metroseksual. Peneliti melakukan wawancara mendalam pada empat informan pria metroseksual di lingkungan Kemenkeu dengan profesi spesifik, usia, dan status yang berbeda.

Kesimpulan dari penelitian ini adalah gaya hidup metroseksual yang dilakukan oleh para informan berada dalam orientasi positif dan tepat. Mereka cenderung narsisme, rapi, berorientasi pada penampilan fisik dan lebih konsumtif. Diamati dari konstruksi presentasi diri informan, profesi ajudan memiliki kecenderungan adopsi gaya hidup metroseksual paling tinggi disbanding profesi lainnya. Berdasarkan karakteristik AIO, hasil penelitian menunjukkan empat tipe gaya hidup pria metroseksual, antara lain tipe sportif, trendy, otomotif, dan artisitik.

Motivasi perilaku metroseksual para informan sejalan dengan siklus metroseksual secara umum. Motivasi beragam yang melatarbelakangi gaya hidup informan yaitu keinginan terlihat menarik terutama pada lawan jenis, tuntutan pekerjaan, dan juga meningkatkan kenyamanan dalam interaksi sosial. Namun, fase-fase metroseksual yang dialami oleh para informan 'tidak bersifat linier' seperti pada umumnya. Jika dikaitkan dengan pola konsumsi, seluruh informan mempunyai minat tinggi terhadap konsumsi. Temuan penelitian menunjukkan bahwa seluruh informan termasuk dalam kategori pembeli impulsif yang berfikir rasional dan selektif.

\section{Kata Kunci: Gaya hidup; Metroseksual;} Modernisasi; Presentasi diri.

\section{PENGANTAR}

Gaya hidup pria metroseksual seringkali menjadi pengaruh nyata arus modernisasi di perkotaan. Laju modernisasi yang merupakan tumbuh sempurnanya kapitalisme tidak hanya mempengaruhi kehidupan ekonomi politik masyarakatnya, namun juga sangat mempengaruhi perilaku sosial individu didalamnya. Menurut ahli ilmu sosial, terdapat tiga jenis perubahan dalam masyarakat, yaitu perubahan peradaban, perubahan budaya, dan perubahan sosial. Perubahan sosial dalam masyarakat merujuk pada aspek-aspek hubungan sosial, pranata-pranata masyarakat, dan pola perilaku kelompok. Salah satu wujdu perubahan sosial masyarakat adalah pergeseran gaya hidup dalam masyarakat yang sejatinya mempengaruhi aspek-aspek hubungan sosial dalam masyarakat tersebut.

Fenomena pergeseran gaya hidup di mana sekarang ini banyak terlihat kaum pria yang sangat memperhatikan penampilan menjadi sebuah contoh nyata pengaruh moderniasasi yang menerpa masyarakat kita. Hal ini memperlihatkan adanya perubahan nilainilai dan definisi tertentu dalam masyarakat karena di masa sebelumnya hal itu hanya lazim dilakukan oleh kaum wanita. Jika pada masa-masa sebelumnya para pria dikenal awam dan enggan untuk singgah pada tempattempat yang menggambarkan perawatan tubuh, kini nereka sudah tidak sungkan lagi untuk bergabung dengan kaum lawan jenis mereka dan melakukan treatment yang serupa. Kalangan ini sering disebut sebagai pria metroseksual yang identik dengan pria berpenampilan rapi, necis, wangi, dan sangat memperhatikan penampilan dirinya.

Sebuah gaya hidup menjadi pembeda satu individu dengan individu yang lain, sekaligus mampu mengukuhkan identitas kepribadian yang ingin dibentuk oleh individu tersebut. Dalam konsep kajian budaya dan media, banyak pakar yang mencoba menjelaskan latar belakang fenomena ini. Kertajaya (2004: 51-52) menggarisbawahi kemunculan kalangan metroseksual adalah adanya pergeseran masyarakat di mana wanita modern mulai mereposisi dirinya sebagai bread-winner (pencari nafkah). Akibatnya, muncul beberapa kondisi bahwa pria mengalami krisis identitas karena peranan yang sejak lama menjadi dasar dalam hubungan sosial telah diambil alih. Selain itu, munculnya kalagan metroseksual juga dipengaruhi adanya trned-setter. Trend setter gaya metroseksual yang digambarkan media sebagai potret kehidupan para artis atau tokoh masyarakat dianggap sebagai role model yang mempunyai arti penting dalam mempengaruhi publik.

Pandangan lain dikemukakan oleh Mark Simpson, seorang kolomnis fashion berkebangsaan Inggris, yang mendefinisikan metroseksual secara sederhana sebagai " $a$ dandyish narcissist in love with not only himself, but his urban lifestyle." Sebagian besar dari 
editorial media memandang metroseksual sebagai manifestasi dari keberhasilan iklan produk-produk kosmetik pria. Namun, para kritikus sosial berpandangan lain. Mereka lebih melihat gejala ini sebagai konsekuensi nyata dari keberhasilan gerakan feminism yang menyebabkan pria meredefinisi peran mereka di ruang publik.

Fenomena gaya hidup metroseksual di kota-kota besar di Indonesia telah menjadi perhatian publik dan sudah dilakukan beberapa penelitian sebelumnya terkait fenomena tersebut. Namun, penelitian mengenai fenomena presentasi diri pria metroseksual di kalangan instansi pemerintah belum pernah dilakukan sebelumnya. Fathia (2006) melakukan penelitian kuantitatif mengenai gaya hidup dan perilaku pengambilan keputusan konsumen metroseksual terhadap pemilihan merk khususnya produk perawatan tubuh dan penunjang penampilan. Sedangkan penelitian kualitatif tentang pria metroseksual telah dilakukan sebelumnya adalah mengeksplorasi kasus metroseksual yang sedang berkembang meliputi gambaran gaya hidup dan perilaku pria metroseksual dalam tinjuan psikologis individu. Sepang (2008) memfokuskan pada studi eksploratif komodifikasi tubuh terhadap pria metrosekual di Jakarta. Ada juga yang melihat tinjauan konstruksi metroseksual dalam iklan yaitu pada studi iklan Men's Biore.

Sejauh ini, belum ditemukan penelitian sebelumnya terkait konstruksi presentasi diri pria metroseksual di kalangan publik khusus salah satunya di kalangan instansi pemerintah. Terkait penelitian mengenai pria metroseksual itu sendiri, kebanyakan penelitian lebih mempersempit pada tinjauan khusus seperti psikologi, pola konsumsi, dan juga periklanan. Fenomena metroseksual dengan mempersempit ruang lingkup hanya digambarkan pada batasan geografis kota besar seperti pria metroseksual di Jakarta, Surabaya, dan kota besar lainnya, sedangkan penelitian dengan batasan kalangan profesi tertentu belum pernah dilakukan sebelumnya.

Mulanya gaya hidup pria metroseksual identik monopoli golongan selebriti oleh media, saat ini bukanlah ciri dari kelas sosial tertentu.
Banyak kalangan yang telah mengadopsi gaya hidup metroseksual, termasuk pria bekerja pada lingkungan birokrasi pemerintahan. Fenomena pria metroseksual di kalangan birokrasi pemerintah menjadi hal mernarik untuk diteliti ditengah stereotipe masyarakat atas birokrasi pemerintah dengan budaya tertutup dan kaku. Konstruksi presentasi diri seorang individu termasuk pria metroseksual menjadi sebuah gambaran siapa dirinya dan selfesteem yg ia miliki di dalam dirinya.

Pertanyaan besar yang lalu muncul adalah "bagaimana konstruksi presentasi diri pria metroseksual di kalangan birokrasi pemerintahan yaitu lingkungan Kementerian Keuangan Pusat sebagai bentuk budaya urban?" Pertanyaan ini sekaligus ingin menganalisa latar belakang atau motivasi pemilihan gaya hidup metroseksual dan juga karakteristik aktivitas yang dilakukan kalangan ini untuk menunjang penampilannya demi membentuk citra diri metroseksual.

Penelitian ini menggunakan metodologi riset diskriptif kualitatif eksploratif untuk memberikan gambaran atas fenomena tersebut. Melalui strategi studi kasus, peneliti memfokuskan penelitian ini sebagai fenomena kontenporer (masa kini) di dalam konteks kehidupan nyata. Populasi penelitian adalah pegawai laki-laki di lingkungan Kementerian Keuangan Pusat pada rentan usia 21-40 tahun yang kemudian dilakukan purposive sampling untuk memenuhi kriteria metroseksual yang ditentukan peneliti. Penentuan usia populasi tersebut dipilih karena masa dewasa merupakan masa yang menunjukkan perubahanperubahan dalam penampilan, minat, sikap dan perilaku yang karena tekanan-tekanan lingkungan tertentu akan menimbulkan masalah-masalah penyesuaian diri yang harus dihadapi oleh orang dewasa, namun perubahan tersebut akan dibawa sepanjang hidup. Sedangkan kriteria pria metroseksual ditentukan peneliti sesuai dengan karakteristik umum metroseksual, yaitu memiliki ciri: (1) pria yang berpenampilan trendi dan rapi; (2) sering melakukan perawatan tubuh dan wajah sehingga terlihat bersih; (3) sering menggunakan parfum dengan aroma cukup 
tajam sehingga tubuhnya berbau harum; dan (4) kebanyakan menggunakan pakaian dan aksesoris yang bermerek.

Peneliti menentukan subyek penelitian kepada empat informan yang memiliki karakteristik yang berbeda-beda melalui wawancara secara mendalam (indepth interview). Keempat informan tersebut adalah Informan 1 (25 tahun, profesi ajudan, belum berkeluarga), informan 2 ( 29 tahun, profesi pranata humas, belum berkeluarga), informan 3 (34 tahun, profesi auditor, berkeluarga), dan informan 4 ( 37 tahun, profesi pelaksana pengadaan dan urusan dalam, berkeluarga). Penelitian ini diperkuat dengan data sekunder diperoleh melalui pustaka seperti buku, jurnal, dan internet.

\section{PEMBAHASAN \\ Gaya Hidup Metroseksual}

Sebagai satu konsep dalam kajian budaya dan media, istilah gaya hidup telah dimaknai sebagai konsep yang kompleks karena menjadi satu bentuk pembedaan sosial dalam masyarakat. Menurut Chaney (2004: 40-41), gaya hidup telah menjadi ciri sebuah dunia modern. Artinya, siapapun yang hidup dalam masyarakat modern akan menggunakan gagasan tentang gaya hidup untuk menggambarkan tindakannya sendiri maupun orang lain. Sedangkan Bourdieu (dalam Ibrahim, 2011:307) menggambarkan gaya hidup sebagai ruang yang bersifat plural yang didaalamnya terdapat para anggota yang membangun kebiasaan sosial mereka atau yang disebut 'habitus'. Dari berbagai makna, diketahui bahwa gaya hidup bersifat kolektif dan tidak tunggal. Gaya hidup adalah hasil kreasi dan adopsi artifisial karena merupakan masalah pilihan. Gaya itu diciptakan, dipraktikkan, dijiplak, dan didaur ulang dalam siklus kehidupan terutama oleh arus konsumsi dan budaya popular.

Metroseksual merupakan sebuah penampakan gaya hidup yang cukup fenomenal di kalangan pria perkotaan saat ini. Istilah metroseksual yang diperkenalkan oleh Mark Simpson, seorang kolomnis fashion berkebangsaan Inggris, banyak menjadi per- bincagan umum di berbagai media baik di Indonesia maupun di negara-negara lainnya mulai tahun 2003 lalu. Sebagian besar dari editorial media memandang metroseksual sebagai manifestasi dari keberhasilan iklan produk-produk kosmetik pria. Namun, para kritikus sosial berpandangan lain. Mereka lebih melihat gejala ini sebagai konsekuensi nyata dari keberhasilan gerakan feminism yang menyebabkan pria meredefinisi peran mereka di ruang publik.

Karakteristik nyata dari pria metroseksual adalah perhatiannya pada penampilan. Naluri narsistik dengan rasa estetika diri yang kuat menjadikan mereka berada pada segmen kalangan kelompok sosial tertentu yang cukup identik dengan penampilan dan fasilitas kelas atas. Dalam kaitannya dengan konsumerisme, kaum pria metroseksual merupakan segmen yang cukup royal berbelanja. Perilaku yang seringkali tergambar adalah kehadirannya di tempat-tempat seperti salon, pusat kebugaran, menggunakan produk kosmetik dengan label 'for men', menggunakan pakaian merk terkenal dan memiliki tingkat adaptasi yang tinggi pada tren yang sedang berlangsung. Dalam hal interaksi sosial, kaum ini cenderung gemar menghabiskan waktu di tempat-tempat ekslusif untuk bersosialisasi. Namun yang perlu menjadi penekanan adalah kaum metroseksual bukanlah gay atau banci, mereka tetap sebagai sosok pria seutuhnya.

Konstruksi media masa menunjukkan bahwa gaya hidup ini menggambarkan sosok pria yang ekslusif sehingga hal ini mendorong kalangan tertentu untuk menirunya. Penggagas citra diri metroseksual mungkin tidak membayangkan implikasi yang luar biasa di kalangan masyarakat luas. Semula hanya berorientasi pada keuntungan penjualan produk, kenyataannya mampu membentuk sebuah kelompok segmen sosial baru yang seringkali masih mendapat persepsi yang beragam di tengah masyarakat. Fenomena inilah yang sekarang ini juga banyak diadopsi oleh kalangan beberapa pria pekerja birokrasi pemerintahan dengan gaya hidup metroseksual. Sejauh ini koridor metroseksual yang telihat adalah membangun citra diri 
yang ekslusif dan menonjol di kalangannya. Di lingkungan Kantor Pusat Kemeterian Keuangan sebagai lokasi penelitian ini, tergambar beragam persepsi atas presentasi diri metrosekual para pekerja pria diantara mereka. Persepsi yang muncul sedikit banyak dipengaruhi sejauh mana pria metroseksual berperilaku di tengah lingkungannya.

\section{Presentasi Diri Pria Metroseksual di Lingkungan Birokrasi Pemerintahan}

\section{Motif Strategic Self Presentation}

Keberadaan individu di masyarakat tergambar melalui selfesteem dan juga social self yg dimiliki individu tersebut. Self presentation merupakan refleksi dari self esteem dan self concept yang ada di dalam diri individu. Dalam identitas sosial seseorang, Glassner dalam Gelles (1995: 205) menyatakan bahwa tubuh dan citra tubuh sangat penting. Seperti halnya pakaian, tubuh juga menjadi obyek dari impression management. Pada tubuh sebagai display, fashion menjadi hal pertama yang paling mudah disuguhkan. Menurut Simmel (dalam Derajat, 2013:279) bahwa "fashion merepresentasikan suatu aksi penyeimbangan antara individuasi dengan keseluruhan ke dalam kehidupan kolektif". Di satu sisi fashion menandai inklusi, sebuah keterhubungan dalam grup sosial tertentu, di sisi lain dapat menegaskan identitas seseorang. Selain itu, Imaji kebugaran (fitness) juga seringkali disuguhkan. Kebugaran juga mencerminkan keadaan ekonomi seseorang dan telah menjadi simbol status kelas sosial seseorang. Untuk mendukung identitas sosial, seseorang berusaha untuk "look the part", di mana cara seseorang berpakaian menawarkan visual metaphor dari identitas.

Terkait dengan konsep diri yang diidentikkan dengan label diri, beberapa informan dengan gaya hidup metroseksual cukup enggan dengan label tersebut. Label metroseksual merujuk pada identitas sosial yang diterima oleh individu, dalam hal ini identitas yang dibentuk oleh kondisi internal individu itu sendiri melainkan membutuhkan persetujuan publik (public validation) yang diperoleh melalui interaksi sosial seseorang.
Menurut mereka label metroseksual yang ada di masyarakat sering dianggap negative, yaitu mengangah ke pria yang kewanitaan atau memiliki orientasi lain, padahal bagi mereka aktifitas yang sedikit berlebihan untuk menjaga penampilan dilakukannya degan alasan yang jelas yaitu terlihat rapi, modis, trendy dan rapi.

\section{"Enggak sih,saya ga suka melabelkan diri saya sendiri. Saya sih ngerasa bukan metroseksual karena memang saya terbiasa penampilan gini lebih pede aja. Penampilan metroseksual itu cuma penilaian orang aja." (informan 4)}

Munculnya self presentation dilatarbelakangi oleh adanya motif-motif yang berasal dari diri individu. Penelitian sebelumnya yang dilakukan oleh Mowen (2002), motivasi seseorang dimulai dari timbulnya rangsangan yang memacu pengenalan kebutuhan. Individu memulainya dari pengenalan kebutuhan akan dirinya. Terkait dengan kebutuhan kaum metroseksual lebih mengarah pada jenis kebutuhan ekspresif yaitu dengan tujuan memenuhi persyaratan sosial atau estetika dan berhubungan dengan pemeliharaan konsep diri seseorang.

Penelitian sebelumnya tentang motif yang melatarbelakangi kaum pria bergaya hidup metroseksual digambarkan dalam sebuah siklus metroseksualitas (dalam Sepang, 2008: 24). Dalam siklus metroseksual ini digambarkan runtutan pergeseran fakta sosial yang menyebabkan lahirnya kaum metroseksual yang dipaparkan dalam beberapa fase. Pertama, fase pemenuh kebutuhan. Pada fase ini menggambarkan keadaan pria-pria normal yang berupaya untuk memenuhi kebutuhannya untuk sekedar tampil lebih rapi dan terlihat menarik. Kedua, fase tuntutan lingkungan. Peralihan ke fase ini umumnya diakibatkan adanya dorongan dari komunitas profesi dan tuntutan pekerjaan yang dijalani. Ketiga, fase menikmati kebiasaan. Bergesernya ke fase ini biasanya terjadi seiring dengan waktu dari yang semula berupa dorongan eksternal menjadi sebuah kebiasaan. Keempat, fase metroseksual. Ini merupakan fase terakhir di mana kebiasaan yang telah dinikmai kemudian 
sampai pada titik jenuh, sehingga individu memulai mengeksplorasi perilakunya.

Dalam penelitian ini, seluruh informan penelitian menunjukkan motif utama yang serupa namun dipaparkan dalam alasan spesifik yang cukup beragam atas motif strategi presentasi diri. Para informan memiliki motif untuk membentuk kesan simpati dari orang lain, di mana mereka ingin terlihat menarik bagi individu lain di lingkungannya dan lebih mengarah pada kebutuhan ekspresif diri. Dalam gambaran siklus metroseksual digambarkan pada fase pemenuh kebutuhan. Alasan spesifik yang diungkapkan para informan salah satunya adalah kepuasan diri untuk terlihat rapi dan bersih.

"Ini lebih karena kepuasan pribadi ngelakuin ini, pokoknya lebih nyaman aja bawaannya. Saya sangat ga suka kalo penampilan saya berantakan apalagi di depan umum, jadi ini merupakan salah satu kebutuhan hidup saya." (informan 2)

Motif spesifik lain juga diutarakan oleh informan karena alasan tuntutan pekerjaan atau dalam siklus metroseksual digambarkan pada fase tuntutan lingkungan. Motif mempresentasikan diri sebagai sosok pria metroseksual yang sangat menjaga penampilan adalah untuk menunjang pekerjaan yang menuntut banyak berinteraksi dengan orang lain.

"Alasannya sih karena kerjaan saya banyak mendampingi pimpinan eselon I dan hadir di berbagai tempat yang ekslusif, jadi kalau kitanya ga rapi dan bersih takutnya malu-maluin aja.. hehe (informan 1)

"Saya kerja di bagian pelayanan yang banyak ketemu orang, saya paling risih kalo liat orang yang penampilannya kotor dan tidak segar, jadi saya balikin ke kondisi sebaliknya, orang pasti lebih betah interaksi dengan saya ketika saya rapi, bersih dan wangi. Penampilan begini bikin saya makin percaya diri." (informan 3 )

Bagi pria metroseksual, lambat laun menjaga penampilan yang selama ini dilakukan tidak hanya dikarenakan motif kesan simpati dari orang lain, namun lebih mengarah menjadi sebuah kebutuhan yang sulit untuk tidak dipenuhi. Ketika rutinitas tersebut tidak terpenuhi akan sangat mempengaruhi rasa percaya diri. Pada siklus metroseksual, temuan ini digambarkan pada fase menikmati kebiasaan.

\begin{abstract}
"Pernah nih sekali waktu saya ga tepat waktu ngurusin rambut, efeknya bener-bener ga pede ketemu orang. Pokoknya kalo ada jadwal yang kelewat nih dan bikin penampilan bakal sedikit berantakan, ga pede banged ketemu orang."
\end{abstract}

Ketidakpercayaan diri merupakan gangguan komunikasi dari faktor pribadi individu. Ketidakpercayaan diri cenderung terlihat dari komunikasi non verbal individu yang seringkali berupa gerak tubuh dan voicetone. Graham et al. (1991) (dalam Nurrohim, 2009) melakukan survei untuk mengetahui dampak komunikasi non verbal dalam organisasi. Studi tersebut menunjukkan bahwa komunikasi non verbal seperti ekspresi wajah, gerak tubuh, dan voicetone memberikan kontribusi sebesar $93 \%$ attitudinal massage pada penerima sangat penting. Selain itu, negative voicetone akan membawa dampak yang kuat terhadap penerima pesan.

\section{Aktivitas Gaya Hidup Pria Metroseksual}

Ulasan majalah SWA 06/XX/18-31 Maret 2004 (dalam Fathia, 2006: 14), pandangan metroseksual dikuatkan oleh Hermawan bukan sekedar behavior, namun "Metroseksual is about mind". Ia menegaskan bahwa dengan adanya peningkatan pendidikan, kemakmuran dan profesi, tak pelak metroseksual tidak akan menjadi tren sesaat. Argumentasi tersebut benar adanya karena hingga saat ini fenomena pria metroseksual semakin marak dan seolah menjadi potret ideal gaya hidup pria modern di perkotaan.

Dalam memahami konsep presentasi diri pria metroseksual, penelitian ini mendasari dengan konsep gaya hidup menurut Assael (1995). Konsep ini melihat gaya hidup sebagai suatu kehidupan dari orang-orang yang terbentuk dari tiga aspek, yaitu aktivitas yang dilakukan untuk memanfaatkan waktu, minat orang-orang yang kemudian menjadi hal yang 
penting dalam lingkungannya, dan pikiran orang-orang tersebut tentang diri sendiri dan lingkungan disekeliling yang tertuang dalam berbagai pendapat. Hal ini juga didukung oleh pendapat Joseph Plumer (dalam Kasali, 2005: 226) bahwa AIO mengukur gaya hidup melalui bagaimana konsumen menggunakan waktu (kegiatan), lingkungan mana yang mereka anggap penting (minat), dan bagaimana mereka melihat diri dan dunia sekeliling (pendapat), serta melalui sejumlah ciri demografis.

Dalam beberapa penelitian sebelumnya terkait pria metroseksual, karakteristik metroseksual seringkali diamati melalui pola konsumsi yang dilakukan. Pria metroseksual cenderung mempunyai minat yang tinggi terhadap konsumsi. Perilaku konsumen (consumer behavior) didefinisikan sebagai perilaku yang ditunjukkan konsumen mulai dari mencari, mengggunakan, membeli, mengevaluasi, dan membuang barang dan jasa yang diharapkan akan memuaskan kebutuhannya (Schiffman, 2007: 3).

Terdapat tiga tipe perilaku konsumtif, yaitu a)konsumsi adiktif (addictive consumption), yaitu mengkonsumsi barang atau jasa kerena ketagihan; b)konsumsi kompulsif (compulsive consumption), yaitu berbelanja secara terus menerus tanpa memperhatikan apa yang sebenarnya ingin dikonsumsi; dan c)konsumsi impulsif (impulsive buying), yaitu berbelanja produk dan jasa memiliki daya guna bagi individu, namun biasanya dilakukan tanpa perencanaan.

Menurut dimensi gaya hidup diatas, keempat informan penelitian memiliki aktivitas pekerjaan yang relatif sama yaitu rutinitas bekerja dalam sehari antara 8-11 jam. Namun, terkait pemanfaatan waktu luang diluar aktivitas kerja, mereka memiliki rutinitas yang berbeda. Pada dasarnya, seluruh informan menunjukkan kegemarannya berolahraga. Namun dua informan menunjukkan aktivitas yang sangat tinggi dalam hal olahraga yaitu dengan megunjungi fitness center setiap 1-2 hari sekali atau bahkan memanfaatkan waktu liburnya untuk olahraga lain yaitu tenis lapangan. Informan menggunakan waktu bervariasi antara 2 jam - 7 jam per minggu.

\begin{abstract}
"Saya sebisa mungkin fitness tiap malam pulang kantor kurang lebih sejam an lah, cuma kalau pas ada deadline kerjaan sampai malam ya enggak, tapi sebisa mungkin dua hari sekali harus lah ke tempat fitness" (informan 1)
\end{abstract}

Informan lainnya memilih mengutamakan aktivitas meet up dengan teman di beberapa kafe terkemuka untuk waktu luangnya. Hal ini minimal dilakukan 1- 2 kali dalam seminggu. Selain itu juga sangat aktif pada kelompok tertentu seperti club mobil dan otomotif. Namun satu informan lebih memilih untuk melakukan treatment wajah dan relaksasi di salon.

"Kalau pas waktu longgar sih saya lebih milih
buat treatment di salon langganan, mulai dari
potong rambut sampe creambath juga. Kalo
waktunya panjang sih sekalian spa dan massage,
biasaya dua minggu sekali, tapi paling tidak
sebulan sekali lah" (informan 2)

Terkait perkembangan tren fashion, pria metroseksual dalam penelitian ini mengaku cukup mengikuti tren terbaru. Posisi mereka dalam kalangan penghasilan menengah, mengharuskan mereka memilah keterjangkauan mengikuti tren yang ada. Selain itu, faktor kepatutan dan kenyamanan juga menjadi ukuran utama mereka untuk memilih fashion yang akan digunakan dalam keseharian.

Produk-produk yang digunakan untuk menunjang penampilan mereka tidak selalu yang menjadi tren terbaru, yang penting sesuai dengan kepribadian mereka. Apalagi mereka juga harus menghindari persepsi berlebihan dari masyarakat atas produk yang dikenakan.

"Saya sih urusan belanja yang realistis aja..
lagian takut salah juga anggapan orang luar kalo
kita pakai yang berlebihan, beli yang perlu dan
kebutuhan rutin sih, cuma buat merk nya sih ga
melulu itu, beberapa kali ganti merk. Apalagi
kalo dapet reviu produk baru dari penjual"
(informan 3)

Tujuan mereka mengkonsumsi kebutuhan penunjang penampilan,, seluruh informan sepakat bahwa perilaku konsumsi yang dilakukan adalah bentuk purpose shopping di mana mereka akan mengkonsumsi barang yang memang dibutuhkan dan memang 
sudah menjadi konsumsi rutin setiap bulannya. Namun, satu diantara informan juga tidak menampik bahwa dirinya terkadang melakukan pleasure shopping dan konsumsi secara impulsif. Hal ini didorong keinginan pada kepemilikan barang dan posisi keuangan yang memungkinkan untuk mengkonsumsi barang sekunder.

"Cuma ya kalo pas ada rejeki lebih ya belanjanya kadang juga lebih dari bulan-bulan sebelumnya.. hehehee Eh pas jalan di mall lihat ada parfum keluaran baru yang kebetulan juga ada potongan harga. Tanpa pikir lagi langsung beli deh, padahal di rumah masih ada parfum." (informan 4)

Dalam hal pilihan konsumsi, kebanyakan dari mereka sangat mengatur pola konsumsinya. Salah satu informan juga sangat detail terkait pola konsumsi dengan memilih makanan tinggi protein. Ia juga mengkonsumsi asupan tambahan lainnya untuk massa otot demi menunjang proporsi tubuhnya semakin ideal.

"Untuk sehari-hari saya yang penting sebisa mungkin menghindari makanan berlemak. Selain itu karena saya rutin fitness jadi biar tubuh ideal saya juga ketat konsumsi makanan tinggi protein. Fitness ditunjang konsumsi rutin konsumsi susu penambah masa otot. Harganya sekitar 1,2 juta sebulan, Cuma ya demi nunjang penampilan sih ya dibela-belain." (informan 1)

Penelitian ini menunjukkan bahwa terdapat empat tipe gaya hidup metroseksual yang ditemukan pada kalangan pria metroseksual di lingkungan instansi pemerintahan. Pertama, tipe gaya hidup sportif yang cenderung menyukai olahraga. Mereka memiliki waktu-waktu khusus untuk melakukan olahraga minimal tiga kali dalam satu minggu dan melakukan minimal dua jenis olahraga. Mereka akan melewatkan waktu luang mereka juga untuk berolahraga. Kedua, tipe gaya hidup trendy yang cenderung suka berinteraksi dengan orang di temattempat ternama. Dalam hal fashion sangat suka untuk mencari tren terbaru sebelum kebanyakan orang memakainya. Pribadi yang setia dan suka diberi penghargaan oleh orang lain. Ketiga, tipe gaya hidup otomotif yang cenderung menghabiskan waktunya untuk hal-hal yang berhubungan dengan otomotif. Mereka cukup aktif dalam keanggotaan club tertentu dan termasuk mudah menyesuaikan diri, perfeksionis, dan berani. Sedangkan tipe keempat adalah tipe gaya hidup artistik di mana informan cenderung banyak menghabiskan waktunya untuk merawat tubuh seperti mengunjungi secara rutin tempat perawatan tubuh. Mereka terlihat berkulit bersih dan mengenakan fashion yang up-to-date dan branded. Selain itu, mereka banyak terlibat menyukai hal-hal berbau seni

Kategori gaya hidup pria metroseksual tersebut didasari pada karakteristik pada AIO yang melihat kecenderungan pria metrosekual menggunakan waktu dan minatnya. Akan tetapi, sesungguhnya keempat kategori bukanlah benar-benar tipe yang berbeda, masih banyak overlapping kecenderungan yang mirip antara tipe satu dengan tipe yang lain. Pembeda yang signifikan adalah derajat kecederungan minat pada hal-hal khusus.

Meskipun mereka memiliki kecenderungan minat yang berbeda-beda namun dapat digarisbawahi bahwa mereka memiliki kesamaan pernyataan mengenai penampilan. Penampilan sehari-hari yang harus menarik, rapi, dan bersih merupakan hal mutlak yang sangat penting bagi mereka. Keempat informan menunjukkan kepedulian yang tinggi terhadap dirinya sendiri. Mereka cenderung menampilkan maskulinitas sebagai citra diri. Dengan proporsi tubuh yang ideal ditunjang dengan gaya penampilan keren baik tatanan rambut rapi, wajah bersih, wangi, dan juga mengenakan pakaian dengan merk ternama dan fit pada tubuh, menjadikan mereka cukup mencolok di lingkungan kerjanya. Gaya metroseksual yang sengaja dicitrakan pada dirinya bukan tanpa alasan, mereka berusaha membangun identitas diri ekslusif pada lingkungan sosialnya.

Terkait pola konsumsi pria metroseksual, kalangan ini didorong oleh keinginan untuk berusaha mengubah citra diri mereka melalui produk karena kebutuhan untuk beradaptasi dengan peran yang berbeda dalam hidup mereka. Selain itu, perihal proses pengambilan 
keputusan konsumen yang kompleks, Henry Assael (1992) (dalam Sutisna, 2002: 16) menjelaskan dalam lima tahap antara lain: pengenalan masalah, pencarian informasi, evaluasi alternatif, keputusan mengkonsumsi dan perilaku pasca konsumsi. Hal ini pun yang banyak dilakukan oleh para informan, meskipun tidak selalu melalui proses pengambilan keputsusan yang kompeks. Sebagian besar informan tidak begitu terpengaruh terhadap merk baru, mereka lebih setia dan loyal pada produk lama yang menjadi andalan

"Saya sih kalo cocok sama merk A biasanya ya tetep itu aja, jarang pindah-pindah ke merk lain apalagi kalo reviu dari orang-orang belum banyak." (informan 2)

Perihal cara pandang pria metroseksual terhadap pola konsumsi produk, seluruh informan menyatakan bahwa mereka cenderung akan mengkonsumsi produkproduk penunjang penampilan mereka. Tak jarang mereka lebih memilih melakukan repetisi mengkonsumsi produk jika memang mereka merasa puas atas produk dan kurang mengindahkan masalah harga produk.

"Saya sih demi penampilan, kadang dibelabelain beli. Apalagi kalo semisal udah cocok nih sama satu produk, ya harga berapapun biasanya saya beli karena memang puas ama hasilnya." (informan 3)

Informan lainnya juga menambahkan, ketika mereka memiliki penghasilan lebih tidak jarang ia akan mengkonsumsi produk lainnya demi menunjang penampilan. Individu dapat mengkonsumsi barang dan jasa yang berbeda sepanjang hidupnya. Persepsi kebutuhan akan suatu barang dan jasa biasanya disesuaikan juga dengan faktor kebutuhan dan usia. Bagi informan yang relatif lebih tua dan berkeluarga, persepsi mereka tentang konsumsi produkproduk penunjang penampilan akan lebih realistis dan tidak terlalu berlebihan.

"Kalau saya soal produk penunjang sih ada produk rutin yang dibeli. Saya ga begitu ngoyo beli buat penampilan sih. Tapi soal pilihan pakaian,saya menghindari pake barang $\mathrm{KW}$, duh langsung ga pede banget." (informan 4)

Merek juga masih menjadi perhatian penting bagi para informan dalam mengkonsumsi suatu produk. Gaya hidup metroseksual yang tercermin pada informan tidak seperti gaya metroseksual pada umumnya yang dikenal kalangan hedonis. Mereka masih cukup realistis dalam melakukan konsumsi atas produk. Kecenderungan mengkonsumsi barang penunjang tambahan lebih dikarenakan adanya harga yang lebih ekonomis salah satunya dalam bentuk potongan harga barang.

\section{SIMPULAN}

Dari proses penelitian dan analisa data yang dilakukan, peneliti menyimpulkan bahwa seluruh informan menunjukkan karakteristik gaya metroseksual. Mereka memiliki pendapat yang sama mengenai penampilan. Penampilan harus terlihat menarik, rapi, dan bersih merupakan hal yang menjadi perhatian. Seluruh informan menunjukkan kepedulian yang tinggi terhadap dirinya sendiri. Gaya metroseksual yang sengaja dicitrakan pada dirinya bukan tanpa alasan, mereka berusaha membangun identitas diri ekslusif pada lingkungan sosialnya. Dalam sudut padang profesi para informan, profesi ajudan memiliki kecenderungan gaya hidup metroseksual dibanding profesi informan lainnya.

Memahami konstruksi presentasi diri pria metroseksual, penelitian ini merujuk pada karakteristik AIO yang diamati melalui kencenderungan pemanfaatan waktu dan minat terhadap hal-hal khusus. Penelitian ini membagi menjadi empat tipe gaya hidup pria metroseksual, yaitu tipe gaya hidup sportif, trendy, otomotif dan artisitik. Keempat kategori ini bukanlah memiliki kecenderungan yang benar-benar berbeda namun hanya memiliki kencenderungan minat khusus yang sedikit berlainan. Minat dominan yang ditunjukkan informan cukup berbeda antara lain pria metroseksual yang gemar olahraga, gemar otomotif, intensif merawat tubuh, serta berinteraksi dan berkumpul pada kelompok khusus. 
Motivasi yang mendorong perilaku metroseksual pada informan menunjukkan kesesuaian dengan siklus metroseksual pada umumnya. Dalam siklus metroseksual digambarkan dalam empat fase yang dimulai dari fase pemenuh kebutuhan, fase tuntutan lingkunagn, fase menikmati kebiasaan, dan fase metroseksual. Dalam penelitian ini, peneliti menemukan bahwa fase-fase yang dialami oleh informan 'tidak bersifat linier'. Terbukti dari hasil wawancara yang dilakukan fasefase tersebut tidak terjadi secara berurutan. Khususnya fase pemenuh kebutuhan dan fase tuntutan lingkungan, kadang tidak terjadi berurutan, melainkan bersaaan atau bahkan salah satu fase dari keduanya tidak muncul sama sekali. Beberapa informan menunjukkan motivasi gaya hiddup metroseksual karena keinginan berpenampilan rapi, bersih, serta mempertontonkan aura positif yang mampu menarik lawan jenis. Ada juga yang ternyata dilatarbelakangi tuntutan aktivitas pekerjaan. Namun secara garis besar, gaya hidup metroseksual yang dijalani saat ini telah menjadi kebiasaan yang sangat mempengaruhi rasa kepercayaan diri mereka.

Merujuk pada penelitian sebelumnya di mana karakteristik metroseksual seringkali diamati melalui pola konsumsi yang dilakukan, penelitian ini pun menemukan hal yang serupa. Para informan cenderung mempunyai minat yang tinggi terhadap konsumsi. Dalam pengambilan keputusan mengkonsumsi, temuan penelitian menunjukkan para informan termasuk pria yang cukup aktif melakukan konsumsi terkait produk-produk perawatan tubuh dan juga produk penunjang penampilan lainnya. Namun, keseluruhan informan termasuk kategori konsumen impulsif (impulsive buyer) yang akan melakukan konsumsi barang dan jasa yang memiliki daya guna bagi dirinya. Meskipun konsumsi yang dilakukan kadang dilakukan tanpa perencanaan, namun mereka cukup rasional dan selektif memperhitungkan seluruh pengeluaran mereka. Namun, ketertarikan mereka tetap pada barang bermerek dan original karena cukup mempengaruhi percaya diri mereka dalam berinteraksi dengan lingkungan sosialnya.

\section{DAFTAR PUSTAKA}

Assael, H. 1995. Consumer Behaviour and Marketing Action. Ohio: South Western College Publishing.

Chaney, David. 1996. Lifestyles. Routledge. London. Terjemahan Nuraeni. Lifestyles: Sebuah Pengantar Komprehensif. 2003. Jalasutra. Yogyakarta.

Derajat, Zakiyah. 2013. Distro Sebagai Provider Gaya Hidup "Alternatif": Menengok Strategi Distro dalam Usahanya Mempertahankan Eksistensi. Kawistara, 3(3): 277-287

Fathia, Mira. 2006. Gaya Hidup dan Perilaku Pengambilan Keputusan Konsumen Metroseksual terhadap Pemilihan Merek Produk Perawatan Tubuh dan Penunjang Penampilan. Tesis. Program Pascasarjana Ilmu Komunikasi Universitas Indonesia. Jakarta.

Gelles, Riochard J \& Ann Levine. 1995. Sociology, An Introduction $6^{\text {th }}$ ed. McGraw-Hill. USA.

Ibrahim, Idi Subandy. 2011. Kritik Budaya Komunikasi: Budaya, Media dan Gaya Hidup dalam Proses Demokratisasi di Indonesia. Jalasutra. Yogyakarta.

Ibrahim, Idi Subandy. 2011. Budaya Populer sebagai Komunikasi: Dinamika Popscape dan Mediascape di Indonesia Kontemporer. Jalasutra. Yogyakarta.

Kertajaya, Hermawan dkk. 2004. Metrosexual In Venus: Pahami Perilakunya, Bidik Hatinya, Menangkan Pasarnya. MarkPlus\&Co. Jakarta.

Kasali, Rhenald. 2005. Membidik Pasar Indonesia: Sgementasi, Targeting, Positioning. Gramedia Pustaka Utama. Jakarta.

Mowen, John C and Michael Minor. 1998. Consumer Behaviour Fifth Edition. Prentice-Hall. New Jersey. 
Terjemahan Lina Salim. Perilaku Konsumen. 2002. Erlangga. Jakarta.

Nurrohim, Hassa dan Anatan, Lina. 2009. Efektivitas Komunikasi dalam Organisasi. Jurnal Manajemen 7(4): 1-9.

Sepang, Nurul Robbi. 2008. Komodifikasi tubuh: Studi Terhadap Empat Pria
Metroseksual di Jakarta. Tesis. Program Pascasarjana Sosiologi Universitas Indonesia. Jakarta.

Sutisna. 2002. Perilaku Konsumen \& Komunikasi Pemasaran. Remaja Rosdakarya. Bandung. 